\title{
Basic human values and political participation on the internet: Different basic motives for male and female groups
}

\author{
Indro Adinugroho ${ }^{*}$ \& Maya Trisyanti² \\ ${ }^{1}$ Center for Political \& Human Behavior Studies, Faculty of Psychology Atma Jaya Catholic University, \\ South Jakarta, Indonesia \\ ${ }^{2}$ Faculty of Psychology, Atma Jaya Catholic University, South Jakarta, Indonesia
}

\begin{abstract}
Even though participation through the internet has been popular in Indonesia, gender inequality between males and females often affecting the degree of participation. Thereby, identification of basic values that may contribute toward PPI is fundamental to be examined. This study aims to examine the correlation between political participation on the internet and basic values as the predictor in two gender groups, male and female. The result of this study revealed that males and females have different motives for participating in politics through the internet. Female tends to utilize their basic values to support their passive participation while the male is concentrated more on active participation. In conclusion, different basic values as psychological motives in PPI convey different meanings of politics in females and males that should be addressed through different actions.
\end{abstract}

Keywords: political, participation, internet, value, gender

\begin{abstract}
Abstrak
Meskipun partisipasi politik di internet telah populer di Indonesia, namun ketimpangan gender antara laki-laki dan perempuan seringkali mempengaruhi derajat partisipasi. Oleh karena itu, identifikasi nilai-nilai dasar yang berkontribusi dalam PPI sangat penting untuk mengkaji beberapa motif psikologis yang terkait dalam setting politik. Oleh karena itu, penelitian ini bertujuan untuk menguji hubungan antara partisipasi politik di internet dengan nilai dasar sebagai prediktor pada dua kelompok gender, laki-laki dan perempuan. Hasil penelitian menunjukkan bahwa laki-laki dan perempuan memiliki motif yang berbeda dalam berpolitik melalui internet. Perempuan cenderung memanfaatkan nilai-nilai dasarnya untuk mendukung partisipasi pasifnya sedangkan laki-laki lebih berkonsentrasi pada partisipasi aktif. Kesimpulannya, perbedaan nilai dasar sebagai motif psikologis dalam PPI menyampaikan makna politik yang berbeda antara perempuan dan laki-laki yang harus disikapi melalui tindakan yang berbeda. Penelitian ini juga mengungkapkan bahwa internet dapat menjadi salah satu alternatif untuk mendorong partisipasi politik perempuan yang juga penting untuk memperkuat kualitas demokrasi di Indonesia.
\end{abstract}

Kata kunci: partisipasi, politik, internet, nilai, gender

\section{Introduction}

Political participation (PP) which is defined as the willingness to act in political activities to participate in the policy-making process is the fundamental element for a democratic country where society holds the highest authority among all to determine the fate of the nation (Prothro \& Grigg, 1960). In a democratic system, the political system is significantly important to facilitate this authority (i.e., direct election and regulations). Therefore, two aspects, system, and activation are needed as the surveillance mechanism to monitor the performance of the government in delivering effective and efficient policies. By considering the improvement in information technology, there will be an opportunity to expand the degree of political activation on the internet (Mudjiyanto, 2012). The existence of the internet has supported many aspects of human needs, including social and political life in Indonesia. An example can be seen from the existence of www.change.org, a platform to accommodate civil society to monitor the government's decisions through online petitions. Several success stories from various areas, such as environmental policy (Setiawan, 2018) to penal law 
issues (Halim, 2019) have ensued through this platform.

Even though the internet can improve the quality of political participation in society, not all citizens who live in Indonesia are aware of the capability of the internet in delivering political aspiration. A study conducted by Bakker and De Vresse (2011) through survey shows that internet as the medium to support political participation is mostly utilized by the youngster as the generation that closely connected with internet and other online media, whilst senior tends to utilize direct participation. Therefore, several actions in micro, such as giving an opinion on political leader up to macro levels, such as policy advocacy must be considered by the Indonesian government to encourage public participation using the internet as a medium.

Indonesia already had several regulations to empower the public to participate in politics, such as the regulation for direct elections from district level to national level and also the amendment of law No. 2 of 2008 (UU No. 2 of 2008) which regulate the role of political parties in the democratic system. Even though many regulations have been developed to empower political participation, Indonesia is still facing various challenges which affect the quality of democracy in the issues of corruption, regional election (Suyatno, 2016), and also religion and identity in politics (Kiftiyah, 2019; Kurniawan, 2018).

Aside from these, different degrees of political participation among male and female groups in Indonesia are still occurring across places in Indonesia. One of the indicators to represent this phenomenon is a low degree of female representation in the National Parliament (Hidayah, 2018). In essence, female representation is fundamental in the policy-making process to avoid (male) bias due to different needs between both genders. Therefore, creating awareness on female participation is a significant issue for Indonesia and currently internet is a possible medium to support the movement to promote females to be active in politics. The internet can also be the medium to advocate political elites and government to consider this issue as an important aspect in Indonesian politics. The action to encourage and empower the government to care and work for the best interest of the people in forming policies can be named as political participation on the internet (PPI; Anduiza, Cantijoch, \& Gallego, 2009).

As one of the contemporary variables in the field of politics and social science, PPI has been defined as the tendency to participate in numerous political activities to connect citizens with political shareholders, such as government, parliament, political parties, and other political elements through the internet as the medium (Anduiza, Cantijoch, \& Gallego, 2009). A clear connection between public and political elements is important to improve the quality of democracy because citizens might be able to communicate with the government and are capable to deliver their aspirations. Communication between these two parties is important because even though each country has its own unique meaning of democracy, the term itself conveys a general understanding where the highest authority is owned by the society to monitor the government's performance in delivering policies and programs (Munck, 2016).

A study that conducted by Gibson and Cantijoch (2013) explores PPI in United Kingdom participants through two dimensions; active participation (e.g., e-voting and online petition) and passive engagement (e.g., reading online political news) through the internet. Active and passive actions are two keywords that can explain PPI as the fundamental action in politics. This concept is also translated by $\mathrm{Xu}, \mathrm{Ye}$, and Zhang (2018) who propose PPI using three behavioral concepts, (1) contacting government officials; (2) monitoring governmental policymaking process, and (3) collective action and social protest. These three behavioral dimensions can also be categorized into two dimensions of PPI, passive action for point (2) and active action for point (1) and (3). Thus, in this study, the authors use the concept of the dual dimension of PPI and explore it with some items that can likely measure the degree of PPI in the Indonesian context.

Political participation in two sides, online and offline, are the central components of democracy, thus, investigating factors that might be related to the existence of these variables is fundamental. Therefore, the identification of variables which has a connection with PPI is significant for a democratic country, including the country amid democratization like Indonesia. One of the variables being investigated in this study is basic human values. We apply the principle developed by Schwartz (2006; 2012) of basic values which refers to a psychological element that guiding humans in various behavioral responses. The degree of basic human values is varied based on the degree of importance in every human in responding to the situation. For example, when a person sees his or her occupation as the instrument for reaching resources for pleasure, therefore pleasureseeking or hedonism is potentially his or her dominant value among all. Schwartz's value is a cross-cultural theory that can be applied in various cultural contexts across the country, 
including non-Western countries like Indonesia. Many studies have identified basic values using Schwartz's framework as predictors in various attitudes and intentions from attitudes toward ecotourism (Perkins \& Brown, 2012); attitudes toward war (Cohrs, Moschner, Maes, \& Kielmann, 2005); political choice and voting intention (Caprara, Schwartz, Vecchione, \& Barbaranelli, 2008; Heaven, Stones, Nel, Huysamen, \& Louw, 1994) up to attitude towards charity (Stride, 2006). These studies show that different category of values can predict the different form of attitudes that lead to specific behaviors that related to politics. By relying on few studies, it is assumed that basic values, as psychological guidance possible in affecting the degree of PPI.

Schwartz's values have been utilized to examine various intentions and behaviors across contexts from educational (Katılmış, 2017); ecofriendly environment (Ahmad, Kim, Anwer, \& Zhuang, 2020); industry and consumer (Mishra, 2018), and also politics (Fink \& Yolles, 2016). Furthermore, besides the behavioral aspect, basic values can differentiate the subjective goal between males and females. A study conducted by Schwartz and Rubel (2005) from 127 samples in 70 countries reveals that men attribute more importance to some values than women in power, hedonism, achievement, and self-direction, while a woman tends to attach to benevolence and universalism.

Aside from the internal motivation as the reason in political actions, a study conducted by Coffé (2013) using British sample explain that females tends to attach more on a political issue in local level, while males is more connected to a global issue. In the context of Indonesia, gender difference also plays a significant role due to the existence of patriarch belief where man tends to be perceived as the strong leader in many aspects, such as in family (Sakina \& Siti, 2017) up to politics (Nurcahyo, 2016). The existence of the patriarch as a value has been established before the independence of Indonesia due to several reasons, such as religions (Hannah, 2017) and cultural norms (Ariyanti \& Ardhana, 2020). Based on this situation, it can be assumed that patriarch culture might construct a different perspective in the female group in seeing politics and some related actions to it. Thus, investigating basic values may become an alternative to find the answers.

Considering many empirical studies which explore the correlation between gender differrence, basic values, and political participation, further investigation to assess different pathways between basic values and political participation in male and female groups is needed.
This action is fundamental to understand the internal motivation to act in politics. Thus, political participation on the internet is considered in this study as the outcome variable due to massive improvement on the internet and other digital features which facilitate political actions nowadays (Huang, Su, Han, \& Weatherall, 2017; Lee, 2017). Understanding internal motives through basic values between males and females can be valuable insight to improve the quality of Indonesian democracy where effective and efficient intervention to promote public participation can be made. Therefore, when there is equality in participation between males and females, bias in the policy-making process can be reduced and the principle of democracy can be applied.

As an attempt to explore the connection between two variables in male and female groups, regression and correlation are conducted in this study to examine the degree of contribution of basic values as predictors toward PPI as the outcome variable. To collect the data, authors applied quantitative self-report form, Portrait Values Questionnaire (PVQ; Hinz, Brahler, Schmidt, \& Albani, 2005) that can be applied in the non-western sample and PPI selfreport form (PPI-S) which was constructed by the authors by applying the framework from Gibson and Cantijoch (2013). The construction of PPI-S is formed under the consideration of the situation that mostly occurs in Indonesia. Authors hypothesized that male and female groups have different motives and purposes which are reflected through basic human values affecting their online political actions. Moreover, values that contribute to female groups are values that might be related to positive emotion, such as caring and equality among others, whereas, for male groups, values that can be related are excitement, challenge, and the sense of independence.

\section{Participants}

\section{Methods}

Over 311 students from various universities who live in Jakarta, Depok, and Bekasi participated in this study. The selection of these territories was based on the consideration of these locations as big cities where internet connection exists and is reliable (Rizkinaswara, 2019). Students are selected as the sample based on their characteristics as the future generation of Indonesian politics. Demographic data shows that participants are dominated by females (64\%) compared to the male group $(35 \%)$ with the age range from 17 to 30 years old $(M=22.23 ; \mathrm{SD}=2.34)$. Related to internet 
usage, all participants have been using the internet for over 12 years on average. From this data, it can be seen that most of the participants who participated in this study are millennials and Gen Z \& Y (digital natives) who were born after 1990.

By considering internet and political issues as two connected topics which might affect the result of this study, the authors also ask some questions that are related to the frequency of internet usage and participant's opinion related to Indonesian political issues as described in
Table 1. Attitudinal scale through summated rating scale from 1 (very unlikely) to 5 (very likely) is applied in each question to assess the degree of agreement or disagreement in each item. The result in Table 1 shows that our participants tend to have a higher degree in accessing, getting information, and sharing information from online sources. As for political interest, questions number 6 and 7 reveal that participants tend to have a moderate degree in responding to political issues that exist in Indonesia.

Table 1

Demographic information related to participants activities in the online medium and political interest

\begin{tabular}{|c|c|c|}
\hline Demographic questions & Mean & SD \\
\hline $\begin{array}{l}\text { (Q1) How often do you use online media (news, site, blog, or } \\
\text { social media)? }\end{array}$ & 4.38 & 0.77 \\
\hline $\begin{array}{l}\text { (Q2) How often do you get information from online media } \\
\text { (news, site, blog, or social media)? }\end{array}$ & 4.37 & 0.69 \\
\hline $\begin{array}{l}\text { (Q3) How often do you share information through online } \\
\text { media (news, site, blog, or social media)? }\end{array}$ & 3.10 & 1.17 \\
\hline $\begin{array}{l}\text { (Q4) How often do you respond to posted news in online } \\
\text { medium (news, site, blog, or social media)? }\end{array}$ & 2.43 & 1.14 \\
\hline $\begin{array}{l}\text { (Q5) How often do you exchange information with others } \\
\text { through online media (news, site, blog, or social media)? }\end{array}$ & 2.67 & 1.25 \\
\hline $\begin{array}{l}\text { (Q6) How often do you follow any updates related to } \\
\text { Government and policy? }\end{array}$ & 3.37 & 0.90 \\
\hline (Q7) How do you like political issues in Indonesia? & 3.03 & 1.15 \\
\hline
\end{tabular}

\section{Data collection procedure}

As an attempt to collect responses from participants, the authors applied the purposive sampling technique, a sampling technique to find specific participants who meet the detailed criteria who are higher than 18 years old (Etikan, Musa, \& Alkassim, 2016). This characteristic is chosen due to the fact that participants are able to make legitimate political action through voting. Voting is said to be the important element for participants to be selected because when participants are able to give their voice in the election, there will be a legitimate privilege to criticize the government (Hardjaloka \& Simarmata, 2016). Selected participants are shared with the link which directs them to access the online form. Before participants can go to the demographic questions and the main instruments, informed consent is shown at the beginning of the page. Participants who are agreed to participate can choose the next button to be involved.

\section{Measuring political participation on the internet}

Studies from across countries have shown that political participation is related to numerous political behaviors such as voting, contacting government officials, and demonstration (Conover, Zarate, Camacho, \& Baez, 2020; Croke, Grossman, Larreguy, \& Marshall, 2016; Djupe, McClurg, \& Sokhey, 2017). Due to rapid changes in information and technology which might affect several aspects of human behavior, political participation becomes the variable that might be affected through this world transformation. Internet as an online medium exists to facilitate many political motives and aspirations through a variable named political participation on the internet (PPI) which defines as behaviors to affect government policy-making process through the internet as the primary tool. An example of this behavior can be seen from sharing political news to others and signing e-petition to support or decline new outgoing policies. However, there are some requirements in offline participation that does not that significant in PPI, such as civic skills based on the examination from Best and Krueger (2005). 
Based on the consideration that political participation is possible to be affected by several variables, the development of PPI-S will rely on the two empirical dimensions, which are passive and active participation (Gibson \& Cantijoch, 2013). These two dimensions are chosen due to the consideration as the fittest theoretical framework to explain online behaviors in the Indonesian context, particularly behavior that is mostly related to political action using the internet, such as consuming political news through online platforms or creating online petitions using change.org.

Therefore, by relying on these two dimensions, items were also developed by considering various social contexts in Indonesia (e.g., how Indonesian access online news and how they respond to political information). Furthermore, consideration regarding online activities in Indonesia is also discussed in the team in order to finalize the items. Some items in measuring active participation on the internet are "I give my opinion about the policy made by the President through an online medium"; "I share my opinion related to the tweets from my President" and "I make the e-petition to criticize regulations which might bring negative effects to the society". All the items in this dimension are related to the activities which intend to send a message to the government and possibly to deliver changes.

Different from active participation, passive engagement is more related to the activities related to digesting political information related to politics from online resources, such as online news and blogs. Related to this, few items to represent this dimension are "I receive the information about demonstration from chat application"; "I share the information about politics through chatting application" and "I follow the news update about Indonesian politics from the online media". The range for this scale is considered from 1 (strongly disagree) to 4 (strongly disagree) with the degree of reliability $\alpha=.88$. Based on the argument written by Tavakol and Dennick (2011), any value greater than 0.7 is considering proper and indicating a good reliability level.

\section{Measuring human basic values with portrait values questionnaire}

From the empirical definitions, values can refer to the subjective guidance that can be used to direct behavior in order to achieve subjective and long-term goals in life (Ros, Schwartz, \& Surkiss, 1999; Schwartz, 2012). From those various definitions, the authors finally apply the definition of basic values by referring to Schwartz values theory where basic values are categorized by 10 primary values which characterize humans (Schwartz, 2006; 2012). The uniqueness of Schwartz's values is the nature of this concept which defines as cross-cultural. This is the empirical reason why Schwartz's values might be called as universal values due to its nature where all groups of people have the values differently based on their degree of importance in life. From his studies, Schwartz defines 10 basic values that exist in humans through a circular model, the circle model that classifies theoretical through its correlational dimension (Ross, 1938) described in Figure 1. The circular model inside Schwartz's framework explains value dimensions that have a positive correlation (adjacent) and negative correlation (opposite direction). In this study, the authors also measured the degree of reliability using Alpha Cronbach where the number of the coefficient can be seen in Table 2 .

Table 2.

Dimensions of PVQ and coefficient alpha in each dimension

\begin{tabular}{ll}
\hline Dimension & Alpha coefficient $(\boldsymbol{\alpha})$ \\
\hline Universalism & 0.75 \\
Benevolence & 0.63 \\
Conformity & 0.61 \\
Tradition & 0.52 \\
Security & 0.70 \\
Power & 0.64 \\
Achievement & 0.74 \\
Hedonism & 0.82 \\
Stimulation & 0.68 \\
Self-direction & 0.61 \\
\hline
\end{tabular}

Based on the concept of basic values, Schwartz proposed two types of measurement instruments, named Schwartz Value Survey (SVS; Schwartz, 2006) and Portrait Values Question- naire (PVQ; Cieciuch \& Schwartz, 2012). The two instruments were developed to measure the degree of importance of 10 basic values in participants. However, these two instruments have 
a significant difference in the field of utilization where PVQ is originally developed for measurement purposes in non-western participants who do not obtain the education that focuses on abstract thinking. Based on this empirical consideration, this study utilizes PVQ as the main instrument to examine basic values in Indonesian students as our participants.

Technically, we applied the PVQ which consists of 40 statements as the items which captured an individual's goals, aspirations, and wishes based on the importance of specific values. For example, participants who score high in hedonism, tend to utilize their resources to obtain pleasure and happiness in life. Besides the issue of utilization of PVQ, Schwartz's values are also considered as the cross-cultural theory where it has been assessed in 82 countries around the world. This examination consists of different ethnicities, races, religions, linguistics, age, and gender with a representative sample from 37 countries (Bilsky, Janik, \& Schwartz, 2011; Davidov, Meuleman, Billiet, \& Schmidt, 2008). Based on this consideration, PVQ can be utilized for study in Indonesia, including correlational study due to the characteristic of items. Some example of items for Schwartz's values are "thinking up new ideas and being creative is important to him. He likes to do things in his own original way" for self-direction values, "it's very important to him to make to help the people around him. He wants to care for their wellbeing" for benevolence values and "he thinks it is important that every person in the world be treated equally. He believes everyone should have equal opportunities in life" for universalism value.

\section{Result}

\section{Gender difference and political participation on the internet}

As for the first phase, authors investigate whether PPI is understood differently by male and female groups by calculating mean scores and $t$-test between males and females. This examination is conducted based on several studies which focusing on (offline) political participation in Indonesia, such as the study from Gama and Widarwati (2008) who emphasize the different responses towards politics from male and female groups. This study shows that the female group is likely to be seen as the group who intends to avoid politics in their life due to several reasons. Not just in a developing country like Indonesia, this finding is also found in a developed country, as the study conducted by Morales (1999) explores that the gender gap affects the degree of political participation in Spain. For Indonesia, patriarch culture (Nimrah \& Sakaria, 2015) and gender role (Sari, 2009) are the strong assumptions to explain why the female group tends to have a lower degree in political participation. As one of the indicators, it can be seen with a small representation of members in parliament who are female that every year, the suggestion to fulfill $30 \%$ of female representation in parliament cannot be met by many political parties in 2019 (Basuki, 2019).

It can be suggested from Table 2 that males and females tend to have different scores in the two dimensions that male tends to have higher score in both two dimensions, however, comparison test through $t$-test for independent sample shows that the significant difference only situated in AP which refers to the behavior to advocate government and/or public institution in the field of the policy-making process. This result becomes an empirical insight for authors to conduct the next examination and differentiation between male and female will be considered comprehensively. As for the second analysis, authors identify the degree of contribution of gender (male vs female), education, religion, and some demographic questions in Table 1 that related to the frequency of using the online medium to calculate the degree of contribution toward PPI as our outcome variable by relying on linear regression analysis.

Table 3.

Mean Difference of PPI between Male $(n=110)$ and Female $(n=201)$

\begin{tabular}{lllll}
\hline & Male (SD) & Female (SD) & $\boldsymbol{t}(\mathbf{d f})$ & $\boldsymbol{p}$ \\
\hline Passive engagement (PE) & $17.29(4.43)$ & $16.4(4.09)$ & $1.17(309)$ & $>.05$ \\
Active participation (AP) & & & & \\
Total PPI (PE + AE) & $14.50(5.94)$ & $13.1(4.77)$ & $2.27(309)$ & $<.05$ \\
& & & & \\
& $31.80(9.49)$ & $29.5(7.94)$ & $2.27(309)$ & $<.05$ \\
\hline
\end{tabular}


Table 4.

Stepwise regression coefficients toward AP

\begin{tabular}{lllllll}
\hline \multicolumn{1}{l}{ Model } & B & SEM & $\boldsymbol{\beta}$ & t & p \\
\hline 1 & (Intercept) & 9.521 & 0.655 & & 14.529 & $<.001$ \\
& Q4 & 1.673 & 0.244 & 0.364 & 6.869 & $<.001$ \\
& (Intercept) & 8.721 & 0.714 & & 12.213 & $<.001$ \\
& Q4 & 1.194 & 0.300 & 0.260 & 3.979 & $<.001$ \\
& Q5 & 0.735 & 0.274 & 0.175 & 2.685 & 0.008 \\
& (Intercept) & 8.243 & 0.735 & & 11.215 & $<.001$ \\
& Q4 & 1.220 & 0.298 & 0.266 & 4.098 & $<.001$ \\
& Q5 & 0.705 & 0.272 & 0.168 & 2.593 & 0.010 \\
& Gender (M/F) & 1.392 & 0.571 & 0.127 & 2.438 & 0.015 \\
\hline
\end{tabular}

Note. Term Q refers to demographic items related to activities in the online medium and political interest

Table 5.

Stepwise regression coefficients towards $P E$

\begin{tabular}{lllllll}
\hline Model & B & SEM & $\boldsymbol{\beta}$ & $\mathbf{t}$ & $\mathbf{p}$ \\
\hline 1 & (Intercept) & 12.956 & 0.638 & & 20.313 & $<.001$ \\
& Q3 & 1.212 & 0.192 & 0.338 & 6.306 & $<.001$ \\
& (Intercept) & 12.321 & 0.657 & & 18.764 & $<.001$ \\
& Q3 & 0.815 & 0.224 & 0.227 & 3.636 & $<.001$ \\
& Q5 & 0.697 & 0.211 & 0.206 & 3.305 & 0.001 \\
& (Intercept) & 11.821 & 0.686 & & 17.235 & $<.001$ \\
& Q3 & 0.897 & 0.225 & 0.250 & 3.982 & $<.001$ \\
& Q5 & 0.644 & 0.211 & 0.190 & 3.054 & 0.002 \\
& Gender (M/F) & 1.096 & 0.468 & 0.124 & 2.340 & 0.020 \\
\hline
\end{tabular}

Note. Term $Q$ refers to demographic items related to activities in the online medium and political interest

The result from regression using the stepwise method shows that gender difference plays a significant role in affecting the degree of PPI both in Model 3 for AP $(\boldsymbol{\beta}=.12 ; \mathrm{p}<.05)$ and PE $(\boldsymbol{\beta}=.12 ; \mathrm{p}<.05)$. Furthermore, results in Table 3 and Table 4 also reveal another insight related to two dimensions, where AP tends to attach more to online activities that are related to responding and exchanging online information, whilst PE is more connected to sharing and exchanging information. In conclusion, results from Table 2, Table 3, and Table 4 indicate that gender affects not just degree in PP but also the types of political actions. These results are aligned with a study conducted by Coffé and Bolzendahl (2010) through 2004 International Social Survey Program (ISSP) data for 18 advanced western democracies. This study argues that women tend to have a higher degree in private activism when it comes to politics rather than men who like to address active participation and direct contact.

\section{The connection between basic values and PPI}

Statistical analysis in Table 2 and Table 3 shows an interesting result of how different gender groups, male and female, deliver their activation on the internet to participate in the political process through the internet. Even though the male group is likely to have a higher degree of PE and AP, but the further investigation should be addressed more in the relation between basic values and PPI for those groups. In this examination step, the authors investigate the stated hypotheses through a correlation matrix between male and female groups. Examination by contrasting between male and female groups are conducted based on the previous result in Table 1 , Table 2 , and Table 3 which indicates that different gender can give meaning to how participants active in online mediums to affect government policy. Thus, with Pearson correlation, the statistical analysis to calculate the degree of correlation between two variables is applied in this study. Justification can be made through the level of significance is 95\% and 99\% confidence interval. Overall, males and females 
have different profiles in the relationship analysis between two dimensions of PPI and basic values. Further explanation in each segment will be discussed through four basic values domains.

Table 6.

Correlation Matrix (r) between PPI and Basic Human Values based on Gender Classification

\begin{tabular}{|c|c|c|c|c|}
\hline \multirow[b]{2}{*}{ Basic values } & \multicolumn{2}{|l|}{ Male $(n=110)$} & \multicolumn{2}{|c|}{ Female $(n=201)$} \\
\hline & $\begin{array}{l}\text { Active } \\
\text { participation }\end{array}$ & $\begin{array}{l}\text { Passive } \\
\text { engagement }\end{array}$ & $\begin{array}{l}\text { Active } \\
\text { participation }\end{array}$ & $\begin{array}{l}\text { Passive } \\
\text { engagement }\end{array}$ \\
\hline Benevolence & .18 & $.19^{*}$ & $.19^{* *}$ & .12 \\
\hline Universalism & .17 & .18 & $.21^{* *}$ & $.18^{*}$ \\
\hline Self-direction & $.20 *$ & .15 & .10 & .08 \\
\hline Stimulation & $.30^{*}$ & $.23^{*}$ & .13 & $.14^{*}$ \\
\hline Hedonism & $.21^{*}$ & $.24^{* *}$ & $.22^{* *}$ & $.24^{* * *}$ \\
\hline Achievement & $.26^{*}$ & .11 & $.33^{* * *}$ & $.35^{* * *}$ \\
\hline Power & $.38^{*}$ & $.27^{* *}$ & $.26^{* * *}$ & $.17^{*}$ \\
\hline Security & $.21^{*}$ & $.19^{*}$ & .11 & .05 \\
\hline Conformity & .17 & .10 & $.29^{* * *}$ & $.29^{* * *}$ \\
\hline Tradition & $.29 * *$ & $.20^{*}$ & $.18^{*}$ & $.15^{*}$ \\
\hline
\end{tabular}

\section{Self-transcendence as the political motivation for female group}

There are several fruitful insights related to psychological drives and motivations to participate in politics for male and female groups that we can see in Table 3. The result shows that benevolence plays a different role in predicting online political activities, which are passive engagement for the male group and active participation for the female group. According to Schwartz's framework, these values are strongly related to self-belongingness, concern for other's welfare in the society, and other positive psychology variables such as care, love, friendship, responsibility, and loyalty which is also more connected to female groups for their references in behavior. Regarding PPI, the existence of benevolence as a value in the female group is slightly different from the male group where benevolence can contribute to active participation for the female group, whereas the male group does not influenced by this type of value for active participation.

According to Gibson and Cantijoch (2013), active participation is related to various behaviors such as joining in e-petition to criticize policies and contacting government officials through online media. Besides benevolence, another type of value that is also categorized in the self-transcendence dimension is universalism. This value refers to the psychological goal in humans to achieve equality, tolerance, and protection for all people in the world. Standing through Schwartz's theory, universalism tends to be significantly correlated with benevolence. Therefore, it can be suggested that self-transcendence as the value dimension might become the political motivation for the female group to participate in many political actions, particularly to become an active citizen by applying online instruments.

\section{Openness to change is more dominant on male}

If self-transcendence is more focused on female groups as their reference to construct online political actions, then openness to change, a form of value dimension which focuses on seeking knowledge and experience through independence is more connected to the male group. This value dimension is formed through two types of values: stimulation and self-direction. Referring to the result from Table 3, it can be assumed that self-direction and stimulation are more connected to the male group as the contributors in forming their online political actions, particularly in the field of political actions rather than the female group. Moreover, it can also be perceived that male groups are closely related with independent action, challenge, and excitement as the primary characteristics in selfdirection and stimulation. This result is also similar to the study from Coffé and Bolzendahl (2010) which addresses that the male group tends to attach to more active political actions rather than females who tend to join more "private" actions. 


\section{Self-enhancement is important for both male and female groups}

Different from openness to change and self-transcendence which are situated differently as the goal for conducting political actions for male and female groups, self-enhancement as a value dimension is important for both groups. This value dimension refers to the subjective goal to obtain social superiority and esteem through three types of values: achievement, power, and hedonism. Based on the result, power becomes the most dominant predictor for active participation rather than passive engagement. This argument can be articulated due to politics and public participation is related to the business of dominating other groups (Pratto, Sidanius, Stallworth, \& Malle, 1994) and sharing specific ideology through public policy. For example, individual who joins Islamist party tends to promote Sharia Islam as their ideology.

In regards to achievement value, PPI for the female group can be predicted through achievement for two dimensions, active participation $(r=.338$; $\mathrm{p}<.05)$ and passive engagement $(r=.355$; $\mathrm{p}<.05)$. However, males are only significant in predicting active participation $(r=.265$; $\mathrm{p}<.05$ ) with a lower degree of correlation compared to females. Moreover, hedonism as the sense for seeking pleasure for oneself might be contributed to how female and male groups participate in politics through online media. Based on Schwartz's framework, hedonism is the value that might contribute to the degree of self-enhancement. The explanation for this correlation can be various, for example, PPI can become an instrument to maintain pleasure and stimulate their life as the citizen though various activities, such as criticizing government or sharing e-petition.

\section{Conservation is also promoting PPI}

Security, conformity, and tradition are three values that can be aggregated and forming a value dimension named 'conservation'. Result also shows that these three values are significant predictors of PPI. According to the definition, conservation refers to the intention to maintain cultural tradition, harmony, and the social structure which has been established in the society (Schwartz, 2012). Similar to openness to change, this connection can be interpreted through multi-perspective aspects. One of the possible explanations can be stated to understand this correlation where online political actions are possible to become the instrument for keeping this regularity in the society by influencing or rejecting the specific policies that might be harmful for their tradition. In Indonesia, change.org is the popular online platform to facilitate individuals or groups to criticize new policies and regulations, including maintaining the life and everyday activities of indigenous people who live across islands in Indonesia to get their rights. One of the online petitions was started by Hindrati in 2018 to encourage the government to care about the cultural rights of many indigenous people across Indonesia. Up to now, this petition was signed by almost 80,000 people who propose government, particularly the parliament to finalize the draft on the new regulation for indigenous people who live in Indonesia.

Different from tradition, two values in conformity and security are situated differently as predictors for male and female groups. Security is more connected to male group in active participation dimension $(r=.210 ; \mathrm{p}<.05)$ and passive engagement $(r=192 ; \mathrm{p}<.05)$, while conformity is more related to female group both for active participation $(r=.292 ; \mathrm{p}<.05)$ and passive engagement $(r=.299 ; \mathrm{p}<.05)$. Based on this result, security, which refers to the intention to form harmony, safety, and stability in the society, is possible to become psychological references and insights for the male group to conduct their online actions toward government and new policies. It can be assumed that PPI is the instrument to maintain their existing condition. As for the female group, a conformity which refers to the intention to self-restraint some of the everyday actions become the significant predictor for PPI.

\section{Discussion}

This study shows a further explanation from the perspective of psychology why males and females tend to have different degrees of political actions and basic value is the alternative explanation to understand this phenomenon. Many social studies through various perspectives have shown that patriarch culture (Nimrah \& Sakaria, 2015; Nurcahyo, 2016); religious belief (Mukarom, 2008; Sutarto, 2017), and cultural norms, such as gender role (Wibowo, 2011) affecting how female group participates in politics. Review from Pudji (2008) which explore the connection between Islam as the dominant religion in Indonesia suggests that the female group is often perceived as the group who is responsible for the domestic areas, such as in the kitchen, nurturing the children as a mother, and stay at home to support their spouse.

Aside from the religious belief being the encouraging factor that contributes to this issue, the capability of taking risk decisions is also different between males and females. A study 
which conducted by Maxfield, Shapiro, Gupta, and Hass (2010) concerning the issue of risk decision-making through experimental design explains the different behavior between the male and female group. From this study, female is more stereotyped as a risk-averse individual compared to male. Another study which is also supported this result comes from Fehr-Duda, De Gennaro, and Schubert (2004) which utilizes a computer-based experiment in measuring risk decision-making among male and female groups. According to the result, female is perceived as the group who are less sensitive to probability changes and more underestimate regarding the possibility of gains to a higher degree than the male group. Therefore, when we assume that politics is an activity that involved risk decisionmaking, needless to say that different perceptions are also affecting the difference between both genders in political participation.

Even though many studies have shown various empirical statements to support the argument of female tends to have a lower degree of political participation, particularly in Indonesia, this study shows a slightly different argument with some of the previous studies which focus on offline participation. In the online setting, this study shows that gender is not significantly affecting the degree of PE, one of the dimensions in PPI. Thus, it can be assumed that the internet can be the alternative to promote participation by females and bypass some cultural partitions which often exist in the female group and inhibit their activities in politics, such as religious ideology, patriarch culture, and other social norms.

Through the internet, every person, without considering their religion, gender, and social status can participate and express their aspirations anytime, anyplace, and borderless. The existence of the internet can eliminate many variables which usually inhibit human behavior to actively participate in politics, such as time and place to coordinate demonstration or direct advocacy. Various social mediums on the internet, such as online political news or an online platform to communicate and discuss can function as the instrument to attach people with many political issues, movements, and civic responsibility in a democratic country.

Based on this study, the female group is not completely alienated in the online setting to participate in politics. This argument is supported through the result which shows no significant difference between male and female groups in the passive engagement dimension. Therefore, this dimension which addressing to behaviors in seeking political information in the online setting is the opening gate for the female group to start actively participates in politics. Intervention and instruments to support the female group to access political information should be encouraged more in this area as an attempt to keep increasing the level of participation.

Moreover, this study also shows different values which describe the different motives between male and female groups in showing their activities related to politics. For example, the female tends to utilize self-transcendence, which is categorized with two dominant values, benevolence and universalism, as their reference to conduct online participation compared to the male group. In conclusion, the internet which consists of various online mediums must be explored and utilized to support gender equality in Indonesia where women should be digitally facilitated through the existence of the internet and online mediums. This argument is possible to be actualizing due to the nature of the internet that is boundless; does not define a person based on social class, religion, culture, economic status, or identity.

\section{Conclusion}

The primary limitation of this study is situated on the sample characteristic where most of the participants are dominated by university students. Therefore, generalization on the result should be done specifically addressing those groups. University students are the representation of educated group where the female group should have better knowledge and critical thinking over gender role that defines them as a secondary citizen in politics. However, the result from this study reveals the opposite direction where the female group as university students still showing a deprivation in comparison to the male group.

To accelerate the improvement of the democratic situation in Indonesia, the political aspirations from women in politics are significantly needed, because women's needs might different from men. Thus, strategic intervention by applying the internet as the medium to communicate policies is important not just for public dissemination but also to function as an anchor to encourage the public (both men and women) to deliver their opinion and aspiration on various political processes and outputs from the government. Therefore, when the degree of interaction is increased, it can be assumed that gender bias in PPI might be reduced where aspirations from women are also facilitated and appraised. 


\section{References}

Ahmad, W., Kim, W. G., Anwer, Z., \& Zhuang, W. (2020). Schwartz personal values, theory of planned behavior and environmental consciousness: How tourists' visiting intentions towards eco-friendly destinations are shaped? Journal of Business Research, 110, 228-236. https://doi.org/10.1016/j.jbusres.2020.01.0 40

Anduiza, E., Cantijoch, M., \& Gallego, A. (2009). Political participation and the internet: A field essay. Information, Communication \& Society, $\quad 12(6), \quad 860-878$. https://doi.org/10.1080/136911808022827 20

Ariyanti, N. M. P., \& Ardhana, I. K. (2020). Dampak psikologis dari kekerasan dalam rumah tangga terhadap perempuan pada budaya patriarki di Bali. Jurnal Kajian Bali (Journal of Bali Studies), 10(1), 283-304. https://doi.org/10.24843/JKB.2020.v10.i01. p13

Bakker, T. P., \& de Vreese, C. H. (2011). Good news for the future? Young people, internet use, and political participation. Communication research, 38(4), 451-470. https://doi.org/10.1177/009365021038173 8

Basuki, A. (2019, October 3). Melihat Representasi dan Kepemimpinan Perempuan di DPR RI 2019-2024. Antaranews.com. Retrieved from https://www.antaranews.com/berita/10957 50/melihat-representasi-dankepemimpinan-perempuan-di-dpr-ri-20192024

Best, S. J., \& Krueger, B. S. (2005). Analyzing the representativeness of internet political participation. Political Behavior, 27(2), 183216. https://doi.org/10.1007/s11109-0053242-y

Bilsky, W., Janik, M., \& Schwartz, S. H. (2011). The structural organization of human valuesevidence from three rounds of the European Social Survey (ESS). Journal of Cross-Cultural Psychology, 42(5), 759-776. https://doi.org/10.1177/002202211036275 7

Caprara, G. V., Schwartz, S. H., Vecchione, M., \& Barbaranelli, C. (2008). The personalization of politics: Lessons from the Italian case. European psychologist, 13(3), 157-172. https://doi.org/10.1027/10169040.13.3.157

Cieciuch, J., \& Schwartz, S. H. (2012). The number of distinct basic values and their structure assessed by PVQ-40. Journal of
Personality Assessment, 94(3), 321-328. https://doi.org/10.1080/00223891.2012.65 5817

Coffé, H. (2013). Women stay local, men go national and global? Gender differences in political interest. Sex roles 69, 323-338. https://doi.org/10.1007/s11199-013-0308$\mathrm{x}$

Coffé, H., \& Bolzendahl, C. (2010). Same game, different rules? Gender differences in political participation. Sex roles, 62(5-6), 318333. https://doi.org/10.1007/s11199-0099729-y

Cohrs, J. C., Moschner, B., Maes, J., \& Kielmann, S. (2005). Personal values and attitudes toward war. Peace and Conflict, 11(3), 293-312. https://doi.org/10.4324/9780203764190-5

Conover, E., Zarate, R. A., Camacho, A., \& Baez, J. E. (2020). Cash and ballots: Conditional transfers, political participation and voting behavior. Economic Development and Cultural Change, 68(2), 541-566. https://doi.org/10.1086/701211

Croke, K., Grossman, G., Larreguy, H. A., \& Marshall, J. (2016). Deliberate disengagement: How education can decrease political participation in electoral authoritarian regimes. American Political Science Review, 110(3), 579-600. https://doi.org/10.1596/25398

Davidov, E., Meuleman, B., Billiet, J., \& Schmidt, P. (2008). Values and support for immigration: A cross-country comparison. European Sociological Review, 24(5), 583599. https://doi.org/10.1093/esr/jcn020

Djupe, P. A., McClurg, S. D., \& Sokhey, A. E. (2017, March 29). Exposure to discussion and disagreement does not discourage women from political participation any more than men. [Blog Post]. Retrieved from http://eprints.lse.ac.uk/76020/1/blogs.lse.a c.uk-

Exposure\%20to\%20discussion\%20and\%20 disagreement $\% 20$ does $\% 20$ not $\% 20$ discoura ge\%20women\%20from\%20political\%20par ticipation\%20any\%20mo.pdf

Etikan, I., Musa, S. A., \& Alkassim, R. S. (2016). Comparison of convenience sampling and purposive sampling. American journal of theoretical and applied statistics, 5(1), 1-4.

Fehr-Duda,H., De Gennaro, M., \& Schubert, R. (2004). Gender, financial risk, and probability weights. Economics Working Paper Series, No. 04/31,ETH Zurich, CERETH - Center of Economic Research, Zurich. Available http://hdl.handle.net/10419/171475

Fink, G., \& Yolles, M. (2016). Political meaning of mindset types created with Sagiv-Schwartz 
values. European Journal of Cross-Cultural Competence and Management, 4(2), 87-115. https://doi.org/10.1504/ejccm.2017.10004 705

Gama, B., \& Widarwati, N. T. (2008). Hubungan antara kampanye kandidat kepala daerah dan perilaku memilih partisipasi politik wanita (Studi pada ibu-ibu rumah tangga dalam pelaksanaan pemilihan kepala daerah di kabupaten Sukoharjo). Scriptura, 2(1), 6380. https://doi.org/10.9744/scriptura.2.1.63-80

Gibson, R. \& Cantijoch, M. (2013). Conceptualizing and measuring participation in the age of the internet: Is online political engagement really different to offline? The Journal of Politics, 75(3), 701-716. https://doi.org/10.1017/s00223816130004 31

Halim, D. (2019, September 19). Lewat Petisi, Aktivis ini Dorong Jokowi Gagalkan RKUHP. Kompas.com. Retrieved from https://nasional.kompas.com/read/2019/09 /19/12381821/lewat-petisi-aktivis-inidorong-jokowi-gagalkan-rkuhp?page=all

Hannah, N. (2017). Seksualitas dalam alquran, hadis dan fikih: Mengimbangi wacana patriarki. Wawasan: Jurnal Ilmiah Agama dan Sosial Budaya,2(1), 45-60. https://doi.org/10.15575/jw.v2i1.795

Hardjaloka, L., \& Simarmata, V. M. (2016). Evoting: Kebutuhan vs. kesiapan (menyongsong) e-demokrasi. Jurnal Konstitusi, 8(4), 579-604. Retrieved from https://jurnalkonstitusi.mkri.id/index.php/j k/article/view/182/0

Heaven, P., Stones, C., Nel, E., Huysamen, G., \& Louw, J. (1994). Human values and voting intention in South Africa. British Journal of Social Psychology, 33(2), 223-231. https://doi.org/10.1111/j.20448309.1994.tb01020.x

Hidayah, S. N. (2018, August 20). Keterwakilan Perempuan dalam Politik. Detik.com. Retrieved from https://news.detik.com/kolom/d-

4174432/keterwakilan-perempuan-dalampolitik

Hindrati, E. (2018). UU Masyarakat Adat Menjamin Kepastian Hukum Masyarakat Adat. Change.org. Retrieved from https://www.change.org/p/joko-widodo-uumasyarakat-adat-menjamin-kepastianhukum-masyarakat-adat

Hinz, A., Brähler, E., Schmidt, P., \& Albani, C. (2005). Investigating the circumplex structure of the portrait values questionnaire (PVQ). Journal of Individual Differences, 26(4), 185-193. https://doi.org/10.1027/1614-

0001.26.4.185

Huang, M. H., Su, C. H., Han, R., \& Weatherall, M. (2017). How does rising internet usage affect political participation in east asia? Explaining divergent effects. Asian Perspective, 41(4), 527-558.

https://doi.org/10.1353/apr.2017.0024

Katılmış, A. (2017). Values education as perceived by social studies teachers in objective and practice dimensions. Educational Sciences: Theory \& Practice, 17(4).

https://doi.org/10.12738/estp.2017.4.0570

Kiftiyah, A. (2019). Upaya rekonsiliasi politik identitas pasca pelaksanaan pemilu 2019 di Indonesia. Jurnal Analis Kebijakan, 3(1). Retrieved from http://jurnalpusaka.lan.go.id/index.php/jur nalpusaka/article/view/59

Kurniawan, B. (2018). Politisasi agama di tahun politik: Politik pasca-kebenaran di Indonesia dan ancaman bagi demokrasi. Jurnal Sosiologi Agama, 12(1), 133-154. https://doi.org/10.14421/jsa.2018.121-07

Lee, S. H. (2017). Digital democracy in Asia: The impact of the asian internet on political participation. Journal of Information Technology \& Politics, 14(1), 62-82. https://doi.org/10.1080/19331681.2016.12 14095

Maxfield, S., Shapiro, M., Gupta, V., \& Hass, S. (2010). Gender and risk: women, risk taking and risk aversion. Gender in Management. 586-604.

https://doi.org/10.1108/175424110110813 83

Mishra, S. (2018). Understanding consumer behavior towards toxic chemical-free cosmetics using Schwartz values-a study from India. International Journal of Indian Culture and Business Management, 17(2), 185-201.

https://doi.org/10.1504/ijicbm.2018.10015 352

Morales, L. (1999). Political participation: Exploring the gender gap in Spain. South European Society and Politics, 4(2), 223-247. https://doi.org/10.1080/136087404085395 77

Mudjiyanto, B. (2012). Literasi internet dan partisipasi politik masyarakat pemilih dalam aktifitas pemanfaatan media baru. Jurnal Studi Komunikasi dan Media, 16(1), 1-15. https://doi.org/10.31445/jskm.2012.16010 1

Mukarom, Z. (2008). Perempuan dan politik: Studi komunikasi politik tentang keterwakilan perempuan di legislatif. 
MediaTor: Jurnal Komunikasi, 9(2), 257-270. https://doi.org/10.29313/mediator.v9i2.11 25

Munck, G. L. (2016). What is democracy? A reconceptualization of the quality of democracy. Democratization, 23(1), 1-26. https://doi.org/10.2139/ssrn.2299128

Nimrah, S. \& Sakaria, S. (2015). Perempuan dan budaya patriarki dalam politik: Studi kasus kegagalan caleg perempuan dalam pemilu legislatif 2014. The Politics: Jurnal Magister Ilmu Politik Universitas Hasanuddin, 1(2), 173-181. Retrieved from https://journal.unhas.ac.id/index.php/politi cs/article/view/229

Nurcahyo, A. (2016). Relevansi budaya patriarki dengan partisipasi politik dan keterwakilan perempuan di parlemen. Agastya: Jurnal Sejarah dan Pembelajarannya, 6(01), 25-34. https://doi.org/10.25273/ajsp.v6i01.878

Perkins, H. E. \& Brown, P. R. (2012). Environmental values and the so-called true ecotourist. Journal of Travel Research, 51(6), 793-803.

https://doi.org/10.1177/004728751245113 3

Pratto, F., Sidanius, J., Stallworth, L. M., \& Malle, B. F. (1994). Social dominance orientation: A personality variable predicting social and political attitudes. Journal of Personality and Social Psychology, 67(4), 741. https://doi.org/10.1037/00223514.67.4.741

Prothro, J. W., \& Grigg, C. M. (1960). Fundamental principles of democracy: Bases of agreement and disagreement. The Journal of Politics, 22(2), 276-294. https://doi.org/10.2307/2127359

Pudji, T. M. (2008). Citra Perempuan dalam politik. Yinyang: Jurnal Studi Islam Gender dan Anak, 3(1), 316. https://doi.org/10.24090/yinyang.v3i1. 183

Rizkinaswara, L. (2019, August 4). Penggunaan Internet di Indonesia. Kominfo.go.id. Retrieved from https://aptika.kominfo.go.id/2019/08/peng gunaan-internet-di-indonesia/

Ros, M., Schwartz, S. H., \& Surkiss, S. (1999). Basic individual values, work values, and the meaning of work. Applied psychology, 48(1), 49-71. https://doi.org/10.1111/j.14640597.1999.tb00048.x

Ross, R. T. (1938). A statistic for circular series. Journal of Educational Psychology, 29(5), 384. https://doi.org/10.1037/h0057033
Sakina, A. I. \& Siti A., D. H. (2017). Menyoroti budaya patriarki di Indonesia. Share: Social Work Journal, 7(1), 71-80. https://doi.org/10.24198/share.v7i1.13820

Sari, A. (2009). Perempuan dan politik di kota Bekasi (Telaah persperspektif komunikasi gender dalam politik). Paradigma, 10(2), 173-184. Retrieved from http://103.28.220.26/index.php?ref=browse $\& \bmod =$ viewarticle\&article $=19292$

Schwartz, S. H. \& Rubel, T. (2005). Sex differences in value priorities: Cross-cultural and multimethod studies. Journal of Personality and Social Psychology, 89(6), 1010-1082. https://doi.org/10.1037/00223514.89.6.1010

Schwartz, S. (2006). A theory of cultural value orientations: Explication and applications. Comparative sociology, 5(2-3), 137-182. https://doi.org/10.1163/156913306778667 357

Schwartz, S. H. (2012). An overview of the Schwartz theory of basic values. Online readings in Psychology and Culture, 2(1), 2307-0919. https://doi.org/10.9707/23070919.1116

Setiawan, R. (2018, December 20). Daftar Kasus yang Dimenangkan Petisi Change.org Selama Tahun 2018. Tirto.id. Retrieved from https://tirto.id/daftar-kasus-yangdimenangkan-petisi-changeorg-selamatahun-2018-dcnm

Stride, H. (2006). An investigation into the values dimensions of branding: Implications for the charity sector. International Journal of Nonprofit and Voluntary Sector Marketing, 11(2), 115-124. https://doi.org/10.1002/nvsm.44

Sutarto, D. (2017). Gender, politik dan agama. Jurnal Trias Politika, 1(1). https://doi.org/10.33373/jtp.v1i1.716

Suyatno, S. (2016). Pemilihan kepala daerah (pilkada) dan tantangan demokrasi lokal di Indonesia. Politik Indonesia: Indonesian Political Science Review, 1(2), 212-230. https://doi.org/10.15294/jpi.v1i2.6586

Wibowo, D. E. (2011). Peran ganda perempuan dan kesetaraan gender. Jurnal Muwazah, 3(1), 356-364.

Xu, P., Ye, Y., \& Zhang, M. (2018). Assessing political participation on the internet in contemporary China. Chinese Journal of Communication, 11(3), 243-266. 